\title{
MUNICIPIOS RURAIS NA GALICIA DO ANTIGO RÉXIME. O CASO DE VALLADARES: AUTOGOBERNO, XURISDICIÓN E LOITAS SEÑORIAIS
}

\author{
Rodrigo Pousa DiÉGuez \\ Doutor en Historia \\ ORCID iD: http://orcid.org/0000-0001-9323-8728
}

\begin{abstract}
Copyright: (C) 2021 CSIC. La edición electrónica de esta revista se distribuye bajo los términos de una licencia de uso y distribución Creative Commons Reconocimiento 4.0 Internacional (CC BY 4.0).

Cómo citar/Citation: Rodrigo Pousa DiÉGuEz, "Municipios rurais na Galicia do Antigo Réxime. O caso de Valladares: autogoberno, xurisdición e loitas señoriais", Cuadernos de Estudios Gallegos, 68, núm. 134 (2021), págs. 213-239, https://doi.org/10.3989/ceg.2021.134.07
\end{abstract}




\title{
MUNICIPIOS RURAIS NA GALICIA DO ANTIGO RÉXIME. O CASO DE VALLADARES: AUTOGOBERNO, XURISDICIÓN E LOITAS SEÑORIAIS
}

\section{RESUMO}

A Galicia do Antigo Réxime aparece dividida no século XVIII en dous tipos de entidades administrativas que podemos calificar de locais: concellos e xurisdicións. Achegarse ao fenómeno municipal rural de Galicia, pese a ser o maioritario, segue a ser unha tarefa pendente. Se ben se ten afondado bastante no entramado administrativo de varias vilas e cidades as figuras políticas dos concellos rurais seguen a ser auténticas descoñecidas. Partindo disto proponse o estudo do concello de Valladares, integrado na xurisdición de Muros na que coexistía co concello da vila. O seu estudo amosa a capacidade de goberno das comunidades rurais galegas que dirixiu os seus afáns mais aló da xestión dos recursos comunais. A importancia destas unidades tivo como resultado a substracción de prerrogativas sobre o territorio que, de non existir, competerían en exclusiva aos oficiais señoriais de xustiza, e neste caso particular, a súa preservación e resistencia como unidade administrativa fronte á división do territorio baixomedieval do concello entre tres señoríos distintos - Corcubión, Muros e Outes-. A análise dos seus cargos, funcións e os problemas que deberon afrontar ofertan unha radiografía da estratificación social das comunidades rurais e os intereses dos grupos e as súas estratexias.

Palabras ClaVe: Idade Moderna, Século XVIII, Coroa de Castela, Concello, señorío.

\section{MUNICIPIOS RURALES EN LA GALICIA DEL ANTIGUO RÉGIMEN: EL CASO DE VA- LLADARES: AUTOGOBIERNO, JURISDICCIÓN Y LUCHAS SEÑORIALES}

\section{RESUMEN}

La Galicia del Antiguo Régimen aparece dividida en el siglo XVIII e dos tipos de entidades administrativas, que podemos calificar de locales: jurisdicciones y concejos. El análisis del fenómeno municipal rural de Galicia, pese a ser el mayoritario, sigue siendo una tarea pendiente. Por ello, este artículo se propone el estudio de un concejo rural, el de Valladares que, integrado en la jurisdicción de Muros, coexistía con el urbano de la capital jurisdiccional. Su estudio demuestra la capacidad de autogobierno de las comunidades rurales gallegas cuyos afanes no solo se dirigieron a la gestión de los recursos del común. Su importancia tuvo como resultado la enajenación de prerrogativas que, de no existir, tocarían a los oficiales de justicia; y en este caso jugó un papel esencial en la preservación de la unidad territorial bajomedieval, frente a la compartimentación sufrida por la jurisdicción en 3 señoríos distintos. Así mismo, el análisis de los cargos concejiles y sus funciones, además de los problemas que debieron afrontar, proporcionan una radiografia de la estratificación social de las comunidades rurales, los intereses comunes y sus estrategias.

Palabras ClaVE: Edad Moderna, siglo XVIII, Corona de Castilla, concejo, señorío.

\section{RURAL COUNCILS IN EARLY MODERN GALICIA: VALLADARES: SELF-GOVERNMENT, JURISDICTION AND SEIGNEURIAL FIGHTS}

\begin{abstract}
In the $18^{\text {th }}$ century, early modern Galicia was organized into two kinds of local administrative institutions known as jurisdictions and councils. There has been no analysis to date of Galicia's rural municipal phenomenon, despite being the most common; although urban councils have been widely studied, in some cases rural council organisations and officers remain unknown. Therefore, this work aims to study the rural council of Valladares, in the jurisdiction of Muros, which coexisted alongside the urban council of the jurisdiction capital. This study reveals the self-governing ability of rural Galician communities, whose efforts were not only aimed at managing community resources. Their importance resulted in the transference of prerogatives which would have otherwise been in the hands of judicial officials; in this case it played an essential role in the preservation of the territorial unity in the Late Middle Ages, against the division of the jurisdiction into three separate manors. Furthermore, an analysis of the councillors and their responsibilities, as well as the problems they must have faced, provide an outlook of the social stratification of rural communities, common interests and strategies.
\end{abstract}

KeY WORDS: Early Modern Age, $18^{\text {th }}$ century, Castile Crown, council, manor. 
Recibido/Received: 08/07/2020

Aceptado/Accepted: 01/11/2020

\section{OS CONCELLOS RURAIS GALEGOS}

A asociación dos habitantes dun espazo determinado en asembleas que derivaron en concellos propiamente institucionais foi un fenómeno común en todos os reinos da Coroa de Castela ${ }^{1}$. Se ben é certo que os ritmos e formas que adquiriron varían moito duns lugares a outros dependendo dos condicionantes xeográficos, do poboamento e históricos de cada territorio. Así mentres na zona cantábrica da antiga provincia de Burgos a organización destes concellos xirou en torno aos vales fluviais dos que tomaron o seu nome ${ }^{2}$, organizándose nun primeiro nivel por poboacións para logo concorrer nun xunta xeral de cada val, en Galicia o fenómeno xirou en torno aos dous eixos de articulación do territorio baixomedieval e moderno: a parroquia e a xurisdición. Deste xeito o primeiro nivel de asociacionismo galego sería a parroquia ${ }^{3}$, para converxer logo na xuris-

\footnotetext{
${ }^{1}$ Félix J. Martínez Llorente, Régimen jurídico de la Extremadura Castellana, Valladolid, Universidad de Valladolid, 1990, páx. 415; Eduardo HinojosA, en Origen del régimen municipal en León y Castilla, Estudios sobre la Historia del Derecho Español, Madrid, Asilo de Huérfanos del Sagrado Corazón de Jesús, 1903, páxs. 5-7; Antonio SACRISTÁn MartíneZ, Municipalidades de Castilla y León. Estudio Histórico-crítico, Madrid, 1877, páxs. 213-221; Luis García VALdEAVEllano, Curso de Historia de las Instituciones Españolas, Madrid, Biblioteca de Ciencias Históricas, 1973, páxs. 529-540; María del Carmen CARLÉ, Del concejo medieval castellano leonés, Buenos Aires, Instituto de Historia de España, 1968, páxs. 11-39; José A. Anes Duarte Nogueira, "A estrutura administrativa dos municipios medievais. Alguns aspectos", Revista da Faculta de Direito da Universidade de Lisboa, 25 (1982), páxs. 249-317.

2 Agustín Rodríguez Fernández, Alcaldes y regidores. Administración territorial y gobierno municipal en Cantabria durante la Edad Moderna, Santander, Institución Cultural de Cantabria, 1986.

${ }^{3}$ Fernando López Alsina, "La articulación de las unidades de organización social del espacio en Galicia durante la Edad Media: villa, parroquia, terra", en La pervivencia del concepto. Nuevas reflexiones sobre la ordenación social del espacio en la Edad Media, Zaragoza, Universidad de Zaragoza, páxs. 57-111; Hortensio Sobrado CorREA, "Identidad parroquial y comunidad rural en la Galicia de la Edad Moderna", en Campo y Campesinos en la España Moderna, Madrid, FEHM, 2012, páxs. 705-718; Enrique Couceiro Gómez, "Apuntes sobre la endogamia parroquial tradicional y sus condicionamientos socio-económicos e ideológicos en el Bajo Miño”, Anuario Brigantino, 14 (1991), páxs. 301-306; José C. SÁNChEZ PARDo, "Las iglesias rurales y su papel en la articulación territorial de Galicia medieval (ss. VI-XIII), Un caso de estudio", Melánges de la Casa Velázquez, 40 (2010), páxs. 149-170; Camilo FERNÁNDEZ CORTIZO, "Aldeas e caserías a tiro de mano de piedra: los asentamientos rurales en el arzobispado de Santiago (siglos XVI-XVIII)”, Espacio, Tiempo y Forma, 4 (1997), páxs. 211-226; Delfina RodríGUEZ FERNÁNDEZ, “Aldeas y parroquias. La estructuración del territorio en la comarca celanovesa a lo largo
} 
dición; o primeiro nivel de asociación procede do ámbito relixioso e o segundo do político. Como máxima autoridade con capacidade punitiva emanada do seu mero misto imperio os oficiais de xustiza ordinaria funcionaron dende a baixa Idade Media como nexos transmisores e executores das ordes da superioridade: a eles competía a recadación de tributos, homes para os exércitos -señoriais, primeiro, e estatais despois- e calquera outros mandamentos para os que a administración superior non dispuxese de oficial ao cargo ou comisionase un.

Se ben o habitual en Galicia é que concellos e xurisdicións coincidisen nos seus límites, no caso de Muros como no de Noia, Corcubión ou Xinzo de Limia, a existencia dun concello urbano con intereses diferenciados fronte aos dun amplo alfoz levou aos veciños das freguesías rurais a constituír asembleas separadas.

A constitución dos concellos rurais galegos veu determinada por varios factores, pero o piar fundamental, compartido polo fenómeno municipal europeo, foi a unión da comunidade para a defensa dos seus intereses, a xestión dos recursos comúns - esta faríase máis acuciante cando a ecuación recursos poboación estreitaba á súa marxe- ${ }^{4}$, tanto fronte a outras comunidades territoriais como, fronte á superioridade, a Coroa e os señores ${ }^{5}$. Este piar queda en evidencia nas

de los tiempos modernos", Homenaje a la prof. Lola Ferro, Vigo, Universidade de Vigo, páxs. 225-355; Xaquín S. Rodríguez CAMpos, "Os espazos de identidade: reflexións desde a antropolxía social sobre a actualidade da parroquia rural en Galicia", en A parroquia en Galicia: pasado presente e futuro, Santiago, Xunta de Galicia, 2009, páxs. 167-180; Antonio Almeida CAlHEIRos, "A freguesía como unidade político-administrativa mínima en Portugal", A parroquia en Galicia pasado, presente e futuro, Santiago, Xunta de Galicia, 2009, páx. 347; Antoine Follain, "Des communautés paroissales aux communs en Bretagnes et en Normandie. Un conflit pour l'identité communautaire", Annales de Bretagne et des Pays de l'Ouest, 104 (1997), páxs. 33-36; Anne ZINK, Clochers et troupeaux. Les communautés rurales des Landes et Sud-Ouest Avant la révolution, Bourdeaux, Presees Universitaires, 1997.

4 Corina LuchíA, "Poderes locales, monarquía y propiedad comunal en los concejos de realengo castellanos bajomedievales", Anales de la Universidad de Alicante. Historia Medieval, 15 (2009), páxs. 215-237. 5 José María Monsalvo AnTón, "Concejos castellano-leoneses y feudalismo (siglos XI-XII) Reflexiones para el estudio de la cuestión”, Studia Historica. Historia Medieval, 10 (1992), páxs. 203-233; Pau Cateura Bennasser, "Municipi i monarquia en la Mallorca dels segles XIII-XIV", Anales de la Universidad de Alicante. Historia Medieval, 13 (2002); páxs. 43-58; Joan Cruz Rodríguez, "El municipí igualadí medieval: una aproximació al seu funcionament (1282-circa 1388)", Miscellanea Aqualatensia, 8 (1997), páxs. 19-58; Manuel Sánchez Martínez, Fiscalidad de Estado y fiscalidad municipal en los reinos hispánicos medievales, Madrid, Casa de Velázquez, 2006, páxs. 37-48; Bernard CHEVALIER, "Génese de la fiscalité urbaine en France", Revista d'Historia Medieval, 7 (1996), páxs. 21-38; Paolo CAMmoroSANO, "Le origini della fiscallitá publica della cittá italiane", Revista d'Historia Medieval, 7 (1996), páxs. 39-52; Pau Viciano y Antonio J. Mira, "La construcción d'un sistema fiscal: municipis i impost al Pais Valenciá (segles XIII-XIV)", Revista d'Historia Medieval, 7 (1996), páxs. 135-148; Manuel SÁnCHEZ y Pere OrTí, "La génesis de la fiscalidad municipal en Cataluña”, Revista d'Historia Medieval, 7 (1996), páxs. 115-134; Isabel Botelho CARdoso, Concelho e senhorio. O Porto (1385-1433), Porto, Facultade de Letras, 1993; María C. FAlÇAO Ferreira, "Guimarães e Braga nos seculos XIII e XIV: uma questão de poderes”, en $2^{\circ}$ Congresso Histórico de Guimarães, vol. 6, Guimarães, Universidade do Minho, 1997, páxs. 119-130. 
cartas de fuero de moitos territorios que unha vez asentadas as prerrogativas que se intenta protexer proceden a bloquear o aceso á categoría de veciño ${ }^{6}$.

A estrutura adoptada por estes concellos é semellante en tódolos casos, a presidencia do concello pertence ao xuíz ordinario da xurisdición, e, por baixo deste, aínda que estes concellos permaneceron na súa maioría como asembleas abertas, un ou dous veciños de cada freguesía eran elixidos por esta como os seus representantes, asumindo unha dobre función representativa da súa freguesía particular ante o concello e executiva das ordes do concello e o xuíz ordinario en cadansúa parroquia. Reunían en sí características propias dos rexedores urbanos, que lle valeron nalgúns casos denominárense así, coas dos oficiais pedáneos comúns a todas xurisdicións peninsulares compostas por varias poboacións? A maiores distes, cada concello, podía dispor doutros oficios anuais segundo as súas necesidades particulares. Por exemplo, o concello de Avión nomeaba xuíces de montería para as batidas de caza ${ }^{8}$.

Unha das problemáticas máis importantes para o estudo destas institucións é a perda da documentación municipal. A inexistencia de casas municipais, cousa que non sucede nos concellos rurais casteláns ${ }^{9}$, facilitou a perda na maioría dos casos. Sen embargo, a documentación notarial, e os procesos xudiciais, ofrecen unha importante fonte para paliar estas perdas. Neste caso concreto a documentación notarial consérvase no Arquivo Histórico Universitario de Santiago e no arquivo da Real Audiencia de Galicia, no Arquivo do Reino de Galicia, abondan as testemuñas sobre o funcionamento e desenvolvemento da vida municipal de Valladares.

\section{O CONCELLO DE VALLADARES}

O concello de Valladares en Muros toma o seu nome da freguesía que serve de cabeza do concello, por canto as reunións se celebran ao carón da súa igrexa cuxas campás serven para o chamamento. $\mathrm{O}$ costume de reunírense en torno a

\footnotetext{
${ }^{6}$ Félix J. Martínez Llorente, Régimen jurídico de la Extremadura castellana medieval, Valladolid, Universidad de Valladolid, 1990, páx. 433; Rafel GIBERT, "Estudio Histórico-jurídico”, Anuario de Historia del Derecho Español, 52 (1953), páxs. 446-447; Galo SÁnCHEZ SÁnCHEZ, Fueros castellanos de Soria y Alcalá de Henares, Madrid, Centro de Estudios Históricos, 1919, páxs. 97-98.

7 Rodrigo Pousa Diéguez, "La administración de justicia ordinaria en la Corona de Castilla: la división jurisdiccional de Soria en la segunda mitad del siglo XVIII", Cuaderno de Historia Moderna, 45 (2020), páxs. 284-285 y "La fisionomía del poder en la Castilla del siglo XVIII: poder jurisdiccional y poder concejil en Ávila”, Vínculos de Historia, 10 (2021) [en prensa].

${ }^{8}$ AHPOU (Arquivo Histórico Provincial de Ourense), Protocolos, caixa 1797, leg. 3, fol. 13.

9 Pousa Diéguez, "La fisionomía del poder..., 10 [en prensa].
} 
unha igrexa é un fenómeno común cos das xuntas de val cantábricas ${ }^{10}$. A fin de contas as igrexas son o punto de reunión pública obrigada, e o único edificio con afeccións públicas existente en ámbolos casos. De feito incluso en Muros e Noia, as igrexas serven aínda no século XVI como punto de reunión municipal, e nalgúns casos conservan este papel incluso no XVIII -en Muros para as eleccións de escribán do concello, por exemplo--

No caso do alfoz de Muros como en tantos outros a documentación do concello extraviouse, quedándonos tan só as testemuñas da documentación notarial e as da documentación xudicial para o seu estudo e coñecemento. Isto dificulta grandemente coñecer a orixe histórica do concello, se ben sabemos que esta estivo ligada á da propia xurisdición, constituída pola carta de poboamento concedida por Sancho IV á Pobra de Muros ${ }^{11}$, demarcando os seus territorios. Dito documento establecía a dita pobra como capital administrativa e económica das freguesías do seu alfoz, e a obrigatoriedade para os oficiais de residir na vila. O documento non aporta moitos máis datos por remitir ao Fuero de Benavente perdido. A constitución dun concello no alfoz independente do urbano constituía unha violación da carta. En canto a entidade territorial precedente, a terra de Entíns, que perdurou na división eclesiástica, constitúe a base territorial e identitaria deste territorio, polo tanto, con concello ou non, máis antigo que a propia vila portuaria que se intentaba fomentar. De feito o propio documento fai referencia á distancia existente entre o poboamento orixinal, afastado do mar, como a maioría dos que salpicaban a costa galega. A vila tal e como a coñecemos hoxe é un produto baixomedieval superposto.

O paso do núcleo ao señorío arcebispal ${ }^{12}$ conlevou importantes cambios, ao tratarse dun núcleo urbano replicou as institucións e oficios da capital compostelá, e, entre elas, a de dispoñer da súa propia xustiza, dous alcaldes, electos mediante o sistema de cobrados ${ }^{13}$. E que documentamos en funcionamento no século XIV. Este feito foi fundamental para a constitución de dous concellos separados, por canto desmembrou no xurisdicional a vila do seu alfoz, quedando este último baixo a autoridade do xuíz ordinario e facilitando a constitución de dous ámbitos administrativos separados.

\footnotetext{
${ }^{10}$ Rodríguez Fernández, Alcaldes y regidores..., 1986.

${ }^{11}$ María T. González Balasch, Tumbo B de la Catedral de Santiago, [Santiago de Compostela], Seminario de Estudios Galegos; Cabildo de la Catedral, 2004, páxs. 479-480 (doc. 254). Rodrigo PousA DiÉGuez, Señorios costeros y villas portuarias en la Galicia del s. XVIII: Corcubión, Muros y Noia, Vigo, Universidade de Vigo, páxs. 876-879.

${ }^{12}$ Este prodúcese de forma definitiva no reinado de Fernando IV. GonzÁlez Balasch, Tumbo B de..., páxs. 247-249 (doc. 114).

${ }^{13}$ Rodrigo Pousa DiÉGuEz, "Configuración institucional de una villa costera: Muros en el tránsito de la Edad Media a la Edad Moderna”, Espacio, Tiempo y Forma. Serie III. Historia Medieval, 34 (2021) [en prensa].
} 


\subsection{A configuración do concello}

En canto á constitución dos límites do concello coinciden en boa medida cos establecidos na carta puebla do rei Sancho e van paralelos aos cambios xurisdicionais. Sen embargo, o devir histórico e as loitas señoriais polo control da zona, entre os arcebispos e os Mariño de Lobera e Moscosos, darían como resultado dúas situacións diferentes: mentres as freguesías de Carnota ao quedar suxeitas á xurisdición dos Moscoso, condes de Altamira, foron separadas do concello de Valladares; a disputa cos Mariño de Lobeira por varias freguesías non supuxo a súa separación do concello, senón que pese a constituírense nunha xurisdición independente da de Muros, a da Serra de Outes, permaneceron suxeitas no gobernativo ao xuíz de Muros, como presidente do concello de Valladares. Estudemos o desenvolvemento secular de ambas situacións para entender mellor o resultado, e os sucesivos conflitos que se sucederon entre o concello rural de Refoxos, e o de Valladares.

\subsubsection{A Xurisdición da Serra de Outes Mariño de Lobeira}

A presenza da casa dos Mariño na contorna de Muros parece remontarse ao século XII, descoñecemos que condición ostentaban sobre o territorio. Nesta época os territorios compuñan a chamada terra de Entíns. Existía pois una unidade territorial, que perduraría na eclesiástica, pero descoñecemos o réxime xurídico do territorio. A ascendencia dos Mariño sobre a vila que se manifesta no enfrontamento co arcebispo tralo seu paso de reguengo ${ }^{14}$ a señorío podía deberse a esta, pero tamén a mera posesión de bens raíces na vila e na contorna ou outros intereses. Non embargante, a súa forza debía ser abonda obrigando a por fin ao conflito mediante sentencia arbitral permitíndolle conservar a freguesía de Louro en usufruto durante a súa vida, xunto co couto de Arcos da Condesa.

Prodúcese aquí un punto e aparte na presenza dos Mariño na zona, coa morte do fillo de don Paio, este vendería boa parte dos seus bens e ingresaría como dominico en Bonaval ${ }^{15}$. Serán Rui Soga e a súa descendencia os que restablezan o seu dominio neste área erixíndose en señores da fortaleza de Outes. Esta cuxos bastimentos constan nas contabilidades arcebispais ${ }^{16}$, como noutros casos, debeu

\footnotetext{
14 José García Oro y María del Carmen Portela Silva, Los Mariño de Lobeira en la Galicia del Renacimiento. Fortuna y desgracia de un señorío seglar del área compostelana, Santiago de Compostela, Caixa Galicia, 2003, páxs. 9-10.

15 García Oro y Portela Silva, Los Mariño de Lobeira ..., páx. 14.

${ }^{16}$ Mercedes VÁzQuez Bertomeu, La hacienda arzobispal compostelana: libros de recaudación (148183 y 1486-91), Santiago de Compostela, CSIC, 2002 (Anejos de Cuadernos de Estudios Gallegos, 29), páx. 62.
} 
ser cedida ao control da familia por causas descoñecidas ate agora. A primeira noticia da presenza dos Mariño en Muros-Valladares témola cara 1429 don Paio Mariño disputaría ao deán de Compostela diferentes dereito en Muros, entre eles 35 vasalos do alfoz (Valladares). Pouco despois herdaba de dona Constanza Afonso Corredoira, de Noia, bens en Santa Comba de Carnota, Sabardes e San Mamede de Carnota. Morto don Paio, a súa filla, Sancha Mariño aparece en 1495 recibindo lutuosas e curros dos veciños do alfoz de Muros-Valladares ${ }^{17}$.

Todo parece indicar que tanto as posesión dominicais como a tenza da fortaleza de Outes xogaron un importante papel para a constitución dun señorío xurisdicional -constituídos noutros casos simplemente mediante o vínculo de vasalaxe que os contratos enfitéuticos establecían entre terratenentes e colonos-. Como en tantos outros casos - como nos de Deza ${ }^{18}$ ou Pontevedra ${ }^{19}$ - a mitra debeu facer fronte no século XVI a usurpación do seu señorío sobre o alfoz de $\mathrm{Mu}$ ros-Valladares. O concello de Valladares xa existía en 1526, o que favoreceu que independentemente das loitas pola xurisdición o concello permanecese intacto.

En 1546 don Cristóbal Mariño acudía á Real Audiencia defendendo a súa posesión da xurisdición de Outes, e como noutros casos, a sentenza serviu para crear ex novo unha xurisdición inexistente ate entón. Esta erixíase sobre as freguesías de Lira, Carnota, Colúns, Mazaricos, Maroñas, Antes e Abelleira. Con isto non só se usurpaba o señorío arcebispal senón que Lira, couto de Pinario, perdía a súa condición de tal ${ }^{20}$. $\mathrm{O}$ arcebispo recorría a Chancillería, e, estando á proba, optaba por unha solución moi común empregada por Fonseca cos Álvarez Gómez Soutomaior en 1529 ou Antealtares co conde de Lemos ${ }^{21}$. Mediante él concedíaselles a feudo perpetuo, con autorización pontificia, Lira Outes Colúns Mazaricos e Os Baos; restrinxindo o de Maroñas, Arcos, Abelleira, Entíns e Antes cuxa xurisdición sería acumulativa entre ambos señores, quedando as apelacións para o Asistente de Santiago. Así a presidencia do concello de Valladares era privativa do xuíz de Muros e tanto as freguesías acumulativas como as privativas da xurisdición de Outes formarían parte do dito concello e dependerían no gobernativo da súa xustiza -taxa de prezos, control de medidas, pesos e oficios, levas, comparto de tributos, control de feiras, etc.-.

\footnotetext{
17 García Oro y Portela Silva, Los Mariño de Lobeira ..., páxs. 19-20.

18 José García Oro y María de los Ángeles Nóvoa Gómez, La tierra de Deza en la Edad Media y en el Renacimiento. Del anonimato al pleito, Lalín, Concello de Lalín, 2000.

19 José Armas Castro, Pontevedra en los siglos XII a XV. Configuración y desarrollo de una villa marinera en la Galicia medieval, A Coruña, Fundación Pedro Barrié de la Maza, conde de Fenosa, 1992, páxs. 247-260.

${ }^{20}$ García Oro y Portela Silva, Los Mariño de Lobeira..., páxs. 107-108.

${ }^{21}$ María Concepción Burgo LóPEZ, Un dominio monástico femenino en la Edad Moderna: el monasterio benedictino de San Paio de Antealtares, tese de doutoramento, Santiago, Universidade de Santiago de Compostela, 1996.
} 


\subsubsection{O partido de Carnota: loita secular entre Valladares e Refoxos}

Os continuos preitos en torno ao partido de Carnota parecen indicar que a extracción destas freguesías produciuse con posterioridade á constitución do concello de Valladares. Non sorprende isto pois constanos que xurisdición de Corcubión, tal e como a coñecemos en Época Moderna, é un produto moderno constituído a partir de territorios dos Moscoso e outros cedidos polo duque de Arjona, existindo dúas merindades separadas até o século XVI. No mesmo sentido que a fixación de prezos da xurisdición de Outes fose, aínda no século XVIII, unha prerrogativa do concello de Valladares fai pensar na inexistencia dunha xurisdición-concello separado na Idade Media.

A confusa situación de finais do século XV e a escasa documentación non nos permite clarificar por agora a lexitimidade dun ou outro señor sobre os territorios que configuraron o partido de Carnota na xurisdición de Corcubión. En torno a 1474 o conde de Altamira entregaba a Diego de Muros as freguesías de Serres, Carnota e Lariño, que podían formar parte daquelas ocupadas ao arcebispo pola coalición de ambos señores coa axuda de familiares e escudeiros como os Guillelmes de Bendaña ou os Prego de Noia ${ }^{22}$. É cousa sabida que en 1476 a propia vila de Muros estaba como a de Noia baixo o poder destos señores, pasando ao control do correxedor de Galicia e comendador de Bamba, primeiro, ata a fixación do correxemento temporal de Muros-Fisterra-A Pobra ${ }^{23}$, para tornar finalmente ao control arcebispal; perdemos nese momento a pista documental de Serres, Lariño e Carnota que parecen ir a parar ao conde de Altamira como parte da súa xurisdición de Corcubión.

Consecuencia disto son os constantes conflitos de índole municipal entre os concellos de Valladares e o de Refoxos (alfoz de Corcubión) que os fondos da Real Audiencia de Galicia documentan dende o século XVII. Os procedementos non adquiren en ningún momento un cariz xurisdicional, nin os señores nin os seus oficiais de xustiza participan deles, trátase dun conflito municipal sustentado en 3 compoñentes: un histórico, un identitario e un fiscal. En 1656 os veciños do partido de Carnota perseguen a súa incorporación fiscal ao concello de Valladares, e a súa desvinculación do de Refoxos. Estes partidos funcionaban para os repartos que a cabeza de provincia facía de homes e impostos. A tentativa de 1656 era resolta o 10 de novembro por sentenza da Real Audiencia que nega o intento e respecta a coincidencia entre límites municipais e xurisdicionais vixente, ó contrario levaría aos veciños do partido de Carnota a depender no fiscal do xuíz de Muros:

\footnotetext{
22 García Oro, Los Mariño de Lobeira..., páxs. 22-23.

23 AGS (Archivo General de Simancas), RGS (Registro General del Sello), leg. 147.511, 726.
} 
en la administración y paga de las sissas y millones y en todo género de repartimientos [...] caminos, puentes, fuentes, zitas de soldados, contribuciones para ellos y para los montados, carretos y bagaxes todo ello con ynterbención del merino y justicia hordinaria de dicha villa y jurisdizión de Corcubión ${ }^{24}$.

O procurador de Valladares apelará sen éxito. E en 1657 a Real Audiencia confirma en grado de revista a sentencia anterior. O 4 de xullo emite unha carta executoria a petición do procurador do concello de Refoxos para que os veciños do partido de Carnota satisfagan os tributos adebedados dende o comezo do preito. Ante esto o señor do Couto de Badernado ${ }^{25}$, na freguesía de Carnota, e suxeito ao concello de Refoxos recurre á cabeza de provincia, eludindo o ditame da Real Audiencia empregando como testemuña os repartimentos feitos polo concello de Valladares que causaran o preito anterior ${ }^{26}$. A artimaña daba froitos e o rexemento de Santiago emitiu un auto o 27 de abril de 1658 polo que confirmaba a anexión do Couto de Badernado ao concello de Valladares ${ }^{27}$.

Non obstante as controversias sobre a ligazón fiscal de Badernado persistiron e en 1705 o couto era incluido no reparto de 33 soldados que a cabeza de provincia asignara ao concello de Refoxos. Ante a protesta do señor e veciños de Badernado o rexemento de Santiago manifesta a súa mudanza de criterio e manda que o couto quede suxeito nos seguintes repartos e hijuelas ao concello de Refoxos; para, tras a exhibición do auto emitido polo mesmo rexemento en 1658, emitir un novo auto o 21 de maio de 1713 polo que recoñoce a agregación do couto a Valladares para o reparto de tributos, pero mandaos contribuir co soldado adxudicado polo concello de Refoxos.

O concello de Refoxos, pola súa parte, recurría á Real Audiencia servíndose da sentenza obtida en 1657, o 24 de decembro de 1705 certificase a súa copia incluida no proceso. O proceso debeu trasladarse ao rexemento compostelán que mudando de novo o mandato de 1713, mandaba ao concello de Valladares, o 16 de xuño de 1714, devolver os tributos de millóns en carnes pagados por Badernado. O 2 de decembro de 1717 a Real Audiencia ditaba nova sentencia declarando nulos os autos da cabeza de provincia de 1658 e 1713 e suscitaba unha

\footnotetext{
${ }^{24}$ ARG (Arquivo do Reino de Galicia), Real Audiencia, leg. 22.182, núm. 60, s. fol.

${ }^{25}$ García Oro identifica este couto moderno como pertencente á familia dos Muros que coincide coa intención de erixir unha torre no lugar de Burleos, incluído nos seus límites modernos, sen embargo, non é identificable co porto de Villadiego por ubicarse no interior da freguesía. Unha opción é que este dispuxese duns límites superiores e que como outros territorios fose apropiado polos condes de Altamira que no século X tiñan un vínculo estreito coa familia de don Diego de Muros. José García Oro, Diego de Muros III y la cultura gallega del siglo XV, Vigo, Galaxia, 1976, páx. 22.

${ }^{26}$ ARG, Real Audiencia, leg. 22.182, núm. 60, s.fol.

${ }^{27}$ ARG, Real Audiencia, leg. 22.182, núm. 60, s.fol.
} 
nova cuestión agora sí xurisdiccional en torno a creación do couto de Badernado polo conde de Altamira: declaraba nula a creación do couto, condeaba en costas ao seu propietario, o marqués de Mos, e sometía ás partes a perpetuo silencio ${ }^{28}$.

\section{OS OFICIAIS E CARGOS DO CONCELLO}

Os oficiais propiamente ditos do concello serían: a) o presidente por tocar a presidencia aos oficiais de xustiza ordinaria era de provisión señorial e desempeñaron o cargo por trienios; e b) o escribán do concello, tamén de designación señorial, era, pola súa banda, vitalicio e renunciable. Os cargos propiamente ditos serías os de mordomos pedáneos, un por cada parroquia, e procuradores síndicos, dous para todo o concello.

\subsection{Mordomos pedáneos}

O cargo de mordomo pedáneo era anual e electivo. Os mordomos pedáneos son a manifestación máis evidente do pulo pola autonomía municipal, por canto asumen prerrogativas de xustiza -aínda que moderadas- recibidas do xuíz ordinario. A súa presenza e atribucións poñen de manifesto unha estrutura administrativa máis complexa do territorio do Antigo Réxime que a conformada por unha articulación do poder vertical, que tan pouco ten que ver coa realidade castelá, e que ten contribuído a formar unha imaxe simplista e afrancesada que aínda invade os nosos libros de texto e os traballos dalgúns historiadores que pasan por alto as cotas de poder das comunidades rurais, entendendo a administración local unicamente como a administración xurisdicional/señorial. Esta figura non é unha particularidade galega, atopámolos presentes nas poboacións rurais de León ${ }^{29}$ e Castela ${ }^{30}$, en números incluso máis elevados que aquí -o frecuente en Castela e que foran dous por poboación-. A diferencia con respecto a Galicia, débese á xa explicada organización do territorio, e agrupación dos núcleos en parroquias, máis similar a das xuntas de val cántabras, mentres que en Castela as poboacións rurais formaron os seus propios concellos independentes.

$\mathrm{O}$ nacemento dos mordomos pedáneos encadra o paso intermedio entre o concello aberto e o pechado e son consecuencia e manifestación da polarización

\footnotetext{
${ }^{28}$ ARG, Real Audiencia, leg. 22.182, núm. 60, s.fol.

29 Laureano RuBio PÉREZ, Visitas, juicios de residencia y poder concejil en la provincia de León, León, Universidad de León, 1998 y "Poder o poderes. Señoríos, concejos y relaciones de poder en el mundo rural durante la Edad Moderna”, en Aranda Pérez, Francisco (coord.) El mundo rural en la España Moderna, Cuenca, Universidad de Castilla La Mancha, 2004, páxs. 1081-1155.

${ }^{30}$ Pousa DiÉGuez, "La administración de justicia ordinaria..., páxs. 284-285 y "La fisionomía del poder..., [en prensa].
} 
das sociedades rurais e do seu crecemento demográfico. Isto ponse de claro manifesto en lugares como a Extremadura Castelá onde pese a existir outras estruturas administrativas -sexmos e cuadrillas- comezan a xestarse concellos rurais cos seus respectivos representantes pedáneos para defender os intereses en especial dos grupos/individuos máis empoderados ${ }^{31}$. A este respecto a análise destes individuos aínda non permitiu como a dos procuradores establecer perfís claros das elites rurais, pois parece que no seu nomeamento non só interviñeron factores económicos ou estamentais - caso dos clérigos- amosando así que as relacións e os encadramentos sociais do rural galego eran máis complexos que os do mundo urbano.

A elección dos mordomos correspondeu na maioría de casos á veciñanza das parroquias, o que presupón a existencia de xuntanzas parroquiais previas de cara a determinar os candidatos, e a existencia dunha infraestrutura administrativa, de novo similar no seu esquema á das xuntas de val cántabras.

As excepcións están relacionadas coa existencia de coutos non xurisdicionais no territorio de Valladares: nas freguesías de Boa e Fontecada. De modo que os seus propietarios, se ben non puideron enaxear como noutros acoutamentos o dereito a nomear xustiza, privatizaron o nomeamento dos pedáneos dos seus coutos. En Fontecada o dereito a nomear mordomo pedáneo era a mediados do século XVIII de don Xoán Bermúdez de Pontedeume ${ }^{32}$. En Boa, freguesías composta polos coutos de Boa e Taramancos, eran o seus señores os que nomeaban dous mordomos, un por cada couto. Aínda que se nomeaban simultaneamente debido á superior veciñanza do de Boa as tarefas de representación no concello rural eran asumidas durante dous anos consecutivos polo seu mordomo e o de Taramancos só un. Esta cuestión non estivo exenta de conflitos e foi empregada polos veciños de Taramancos para oporse ás decisións dos mordomos de Boa, negando a súa representatividade ${ }^{33}$. A alternancia nos labores propiamente pedáneas establecíase en correspondencia, servindo un para a recepción de ordes da superioridade e o outro para forzas ${ }^{34}$.

As súas funcións variaron dunha xurisdición a outra, as xudiciais dependendo da marxe que os oficiais de xustiza ordinaria lles brindasen e as comunidades rurais puidesen acadar. Estas pasaban polo control das poboacións rurais nas que residían, actuando como delegados e ministros do xuíz ordinario, podendo actuar nuns casos e debendo notificarlle as infraccións noutros. Na nosa linguaxe

\footnotetext{
31 María Asenjo GonzÁlez, Segovia: la ciudad y su tierra a fines del Medievo, Segovia, Diputación Provincial de Segovia, 1986, páxs. 491 y José I. Moreno Núñez, Ávila y su tierra en la Baja Edad Media, siglos XIII-XV, Valladolid, Junta de Castilla y León, 1992, páxs. 130-132.

${ }^{32}$ AGS, Catastro de Ensenada, R. G., lib. 240, fol. 665.

33 AHUS, Protocolos, lib. 1.185, fol. 176.

${ }^{34}$ AHUS, Protocolos, lib. 1.185, fol. 176.
} 
contemporánea as súas funcións comúns foron esencialmente policiais, velando polo mantemento da orde e o cumprimento das ordenanzas municipais, o respecto dos prezos e medidas fixados pola xustiza e a execución das ordes desta e da superioridade. En Refoxos os mordomos chegaron a apropiar o dereito a practicar inventarios pos-morte chegando a preitear cos ordinarios pola violación das súas prerrogativas $^{35}$. Isto cumpría unha función práctica en xurisdicións extensas como a de Muros, o control do territorio por un único ministro era imposible, e estes ministros evitaron a proliferación de tenentes e ministros nomeados polo xuíz, con xurisdición ordinaria delegada, e que nos séculos XV e XVI foran causa de tantos desmáns.

En canto as funcións representativas dependeron do avanzada que estivese a transición do concello aberto ao pechado, así no concello de Posmarcos (alfoz de Noia) as decisións do concello recaían exclusivamente nos mordomos e dous veciños por freguesía, restrinxindo as xuntanzas abertas a cuestións extraordinarias. No concello de Valladares as xuntanzas permaneceron sendo accesibles aos veciños durante todo o século XVIII sen que se detecten restricións á asistencia.

\subsection{OS PROCURADORES SÍNDICOS}

Os procuradores síndicos eran semellantes nas súas funcións aos urbanos, estas xiraban en torno á defensa dos intereses municipais, coa especificidade que en Valladares eran dous, mentres que na propia vila só había un. Eran electos en concello aberto o 16 de xaneiro de cada ano xunto á igrexa de San Miguel de Valladares-ata que as reformas municipais carolinas trasladan a elección de Muros ao día 26 de decembro e a de Valladares ao día 1 de xaneiro ${ }^{36}$-; 10 días despois da celebración das municipais na cabeza da vila que requerían da presenza da xustiza ordinaria para tomar xuramento do cargo. Ademais da defensa e representación do concello fronte a superioridade e os propios xuíces, eran os responsables da recadación das rendas chamadas provinciais, por non existir figura de depositario neste concello, atribuíndoselles por salario o $3 \%$ dos tributos que trasladaban á cabeza de provincia ademais de satisfacer os gastos vinculados aos preitos -en Corcubión satisfacíaselles, por reparto comunal, canto declarasen ter gastado en defensa da xurisdición por mera declaración xurada-. Outra das súas funcións máis importantes dos síndicos de Valladares era a de velar e acompañar ao xuíz para a fixación e prezos dos comestibles -fronte a outros onde as fixaban en exclusiva co xuíz en Valladares o prezo fixábase no

\footnotetext{
${ }_{35}$ ARG, Real Audiencia, leg. 8.963, núm. 38, fol. 1.

${ }^{36}$ ARG, Real Audiencia, leg. 24.153, núm. 17, s. fol.
} 
concello, previa información do que acadaran os produtos en Noia como referencia-, xunto coa de vixiar o control de medidas empregadas para o comercio e a cobranza de rendas. Esta tarefa era importantísima na Galicia do Antigo Réxime por canto, até a incorporación do sistema decimal, as medidas de extensión e capacidade de áridos e líquidos eran distintas dunhas xurisdicións a outras. Nos nomeamentos conservados a veciñanza dáballe poder para representalos ante outras xustizas veciñas ou superiores, e vixiar o ben obrar nas levas de soldados, e compartimentos de bagaxes e aloxamentos de tropas; así como esixir aos xustizas e escribáns a fixación pública dos aranceis reais e o seu cumprimento. Entre os nomeamento e referencias conservados documentamos a varios individuos foráneos ao municipio, pertencentes as elites urbanas de Muros, cuxa presenza ven a manifestar tanto o interese en ocupar os oficios do alfoz, como a existencia de redes e estratexias suficientes para obter o nomeamento -feito documentado tamén nos veciños concellos de Refoxos e Posmarcos- ${ }^{37}$.

O oficio foi disputado e causa de conflito por distintos motivos segundo os casos, os ingresos económicos podía ser atrativos para algúns colectivos, para os outros as procuradorías do común foron un trampolín cara outros postos polo seu carácter honorífico e para outros o control dos prezos. Cara 1740 varios mordomos pedáneos recorren á Real Audiencia para que os síndicos saíntes non permanezan en posesión do cargo como pretenden -declaran que polo interese económico- en contrapartida, outro candidato ofrecerá acceder ao cargo por solo o $2 \%$ de retribución ${ }^{38}$.

Os intentos de manipular a concesión dos cargos foron unha constante dende o século XVII por distintos colectivos documentándose varios casos que remataron en denuncia á Real Audiencia. En 1681 o xuíz da xurisdición da Serra intentaríao asistindo ao concello acompañado do seu escribán de número dous capitáns de milicia e seis alféreces para mobilizar os votos cara os dous procuradores saíntes ${ }^{39}$.

En 1706 serán elixidos dous eclesiásticos, o cura de Entíns e Tarás e o de Outeiro, pese ás denuncias dalgúns veciños, pois consta a asistencia de xente sen

\footnotetext{
${ }^{37}$ Don Francisco Figueroa uno de los rexidores que estavan en la junta llevado del odio y mala voluntad que profesa a la jurisdición y sus naturales por haver acudido barias bezes contra él a la justicia, a fin de que se contuviese en cobrar los frutos de sincura que tenía, a los precios arreglados a la fe de valores por ser sincurero, y hes notirio salió con bozes contradiciendo el poder, dando su boto para procurador general a su compadre don Christobal de Pazos, juez que dispidió, lo mismo que executó don Antonio de Leira, también rexidor sincurero y proveedor del pan para la tropa destacada en dicha villa, quando por lo mismo ni por respecto de rexidores juez ni escribano tienen boz ni boto para las elecciones, porque solamente quando asistan para las que se ofrezcan autorizan las que hagan los naturales. ARG, Real Audiencia, leg. 22.545, núm. 23

38 ARG, Real Audiencia, leg. 9.343, núm. 4, s. fol.

${ }^{39}$ ARG, Real Audiencia, leg. 3.310, núm. 12, s. fol.
} 
voto, son reelixidos. Por comisión da Real Audiencia a elección repítese e don Bartolomé López Fajín, capitán de milicias, consegue facerse co cargo xunto con don Juan Castro Caamaño. A oposición dos pedáneos é unánime denuncian á Real Audiencia a permanencia do cargo durante 5 anos do capitán de milicias, os seus abusos económicos nas levas e a súa condición de comerciantes; ademais o impago de tributos en Compostela orixináralles 26 ducados de multa. A indefensión experimentada polo concello ante o sarxento maior co que acordara o abono de 600 ducados en contraprestación do servizo no castelo de Muros, penando aos que non contribuían con ata 20 gardas, é obxecto de denuncia. Ante isto a Real Audiencia emite novo auto, polo que manda admitir aos eclesiásticos que son reelixidos en marzo ${ }^{40}$. O curas conseguen finalmente os cargos e parece que os mantiveron tamén en 1707, para perdelos en 1708. Chegada a hora de dar contas os eclesiásticos néganse e intentan obter do concello o nomeamento de depositarios, substraendo esta función da procuradoría xeral. Neste clima intervén o arcebispo mandando aos eclesiásticos non se entrometan:

por manera alguna los clérigos no deben entrometerse en los negocios que expesialmente tocan a los legos ni emvaraçarse dicho clérigos en los negocios y juntas que pritivamente tocan al estado secular en virtud de santa obediencia so pena de excomunión.

Ante desobediencia de don Antonio Bermúdez, cura de Coiro, e a sustracción da chave da arca do concello, o arcebispo envía a dous eclesiásticos a apresar ao presbítero o 3 de febreiro que é encarcerado. Unha nova elección é revocada o 18 de febreiro por seren os elixidos fidalgos. Non queda claro se por esta elección ou outra nova en marzo imponse unha multa de 525 ducados a varios veciños por amparar a resistencia dos eclesiásticos e convocar concello sen o xuíz ordinario i a dar fe ao escribán de Noia Antón Álvarez de Castro, cuxas penas acadan os 705 ducados $^{41}$.

En 1753 o xuíz de Muros e o escribán son denunciados polo procurador don Tiburcio Hermida polo intento de manipulación das eleccións. No mes de decembro antes das eleccións manda concorrer á vila aos mordomos pedáneos para persuadilos do nomeamento de don Juan Antonio Caamaño, sincureiro, con quen o xuíz tiña vínculos económicos, sinalando ademais o vínculo de parentesco entre o escribán e a muller do xuíz ${ }^{42}$.

\footnotetext{
40 ARG, Real Audiencia, leg. 13.754, núm. 31, s. fol.

${ }^{41}$ ARG, Real Audiencia, leg. 20.429, núm. 31, s. fol.

${ }^{42}$ ARG, Real Audiencia, leg. 19.448, núm. 72, s. fol.
} 
As eleccións intentan ser manipuladas novamente en 1772. Estas faranse sen asistencia do xuíz e do escribán do concello, baixo a presidencia dun mordomo comisionado e un excusador. Varios veciños recorren a Real Audiencia para denunciar os nomeamentos resultantes que recaen no sobriño do escribán numerario e en don Juan Antonio Campos, sincureiro e recadador de rendas do marquesado de Castelar e a do marqués da Serra, ámbolos dous retiveron o posto durante máis de 6 anos. A Real Audiencia mandará repetir a elección e verificando a materia denunciada que non puideran ser elixibles ${ }^{43}$. En 1779 prodúcese a situación contraria, o xuíz e o escribán numerario negaranse a dar a posesión como procurador electo ao rexedor de Muros, don Vicente Ribeiro Romero, veciño de Muros. Estes aluden á concorrencia de intereses nos sorteos de soldados por ser capitán de milicias e por ser rexedor de Muros poder tocarlle a administración de xustiza en ausencia dos alcaldes e ser o arrendatario das penas de cámara; sen embargo Vicente Ribeiro indica como causa o desafecto do xuíz a consecuencia da súa intervención na toma de residencia ${ }^{44}$.

En 1785 asistimos a outra intromisión das elites urbanas de Muros na vida municipal de Valladares. Esta parece propiciada pola asunción da vara de xustiza por don Bartolomé Patiño, cuxo sobriño tiña asumido, dende 1784, a procuradoría de Valladares, emparentado á súa vez co alcalde e comerciante de Muros don José Calderón. Frustrado o intento de reelección opta por crear a figura de depositario para que poida permanecer como apoderado dos caudais e sen dar contas ${ }^{45}$.

\subsection{O ESCRIBÁN DO CONCELLO}

Se noutros concellos rurais ben non existiu escribanía numeraria, ben esta recaeu automaticamente no escribán numerario por ser só un, en Valladares existiu un escribán de número do alfoz de Muros ao que pertencía privativamente dar fe das xuntanzas e autos municipais e custodiar a documentación.

A escribanía do concello correspondía a un dos seis escribáns de número de Muros, a provisión do oficio correspondía ao arcebispo como señor xurisdicional, pero o usufruto do oficio estaba patrimonializado mediante o sistema de renuncias. Isto quere dicir que o usuario tiña o dereito a renunciar a el e transmitirllo a quen quixese, sempre que se cumprisen as condicións: o renunciante debía estar en pleno uso das súas facultades e a transferencia debía producirse en vida. O traspaso do oficio, cando non se producía de pais a fillos, era empregado como moeda clientelar ou directamente para obter numerario, ou ambos. Por

\footnotetext{
43 ARG, Real Audiencia, leg. 13.115, núm. 18, s. fol.

${ }^{44}$ ARG, Real Audiencia, leg. 24.153, núm. 17, s. fol.

45 ARG, Real Audiencia, leg. 18.051, núm. 1, s. fol.
} 
exemplo, consta que Pablo García Gaioso renunciaríao a favor de Manuel Pérez a cambio de 6.660 reais, 2oo reais anuais, coa condición de que a renuncia de Manuel Pérez se faría a favor de quen o propietario orixinal o fixese ${ }^{46}$. Este tipo de intercambios foron coñecidos e consentidos polo señor e os seus oficiais, como consta das intervencións do Asistente de Santiago nos continuos conflitos aos que este contrato deu orixe ${ }^{47}$.

A existencia da escribanía do alfoz será cuestionada polo resto de escribáns numerarios en 1709, ante a nova provisión do oficio a Pablo García Gaioso, recorren á Real Audiencia. A existencia da escribanía parece xustificada dende 1586 ano do que presente unha ordenanzas asinadas por Bartolomé Suárez, notario público de todo o arcebispado en substitución de Rodrigo Suárez escribán do concello, e entre 1630 e 1650 o oficio parece recaer en don Pedro Romero de Leis, capitán de cabalos, empregando como escusado a José Fernández. Don Pedro Romero lembrado polas testemuñas que afirman que o recibira en herdanza do cura de Beba seu cuñado. Posteriormente, seu fillo don Jacinto Romero arrendaríao a Francisco Méndez Veloso, para vacar e, devolto o dereito de provisión ao arcebispo, concedérselle a José Avalle. Parece que foi a súa vacante durante 20 anos a que propiciou que as funcións recaeran no resto de escribáns de número, que agora se resistían á privación ${ }^{48}$. Non obstante por outro proceso de 1654 cónstanos que algunhas tarefas non foron sempre privativas do escribán do concello de Valladares -mal-nomeado de alfoz-; a visita de termos da xurisdición e o seu amolloamento foi compartida polos escribáns numerarios, disputándose nesa data se se debía facer por quendas, antigüidade ou por elección do xuíz.

\section{Administración municipal e CONFlicto: FiXación de Prezos, SINCUREIROS E COMERCIANTES}

Entre os conflitos de carácter municipal que afectaron a Valladares parecen recorrentes os relativos aos prezos dos abastecementos e froitos. Existían na xurisdición de Muros un elevado número de sinecuras, isto son rendas que non pertencían aos párrocos senón a outros particulares e eclesiásticos, que eran arrendadas a terceiros anualmente para a súa cobranza.

\footnotetext{
${ }^{46}$ ARG, Real Audiencia, leg. 17.803, núm. 34, s. fol.

${ }^{47}$ ARG, Real Audiencia, leg. 17.803, núm. 34, s. fol.

${ }^{48}$ ARG, Real Audiencia, leg. 9.188, núm. 58, s. fol.
} 
Tabla 1. Sinecuras del concejo de Valladares según las R. G. Del Catastro de Ensenada.

\begin{tabular}{|c|c|c|c|}
\hline \multicolumn{2}{|l|}{ Abelleira, santo Estevo } & $100 \%$ & Párroco \\
\hline \multirow{2}{*}{\multicolumn{2}{|c|}{ Alborés, san Mamede }} & $75 \%$ & Párroco \\
\hline & & $25 \%$ & Conde de Maceda \\
\hline \multirow{2}{*}{\multicolumn{2}{|c|}{ Alvite, santo Tomé }} & $67 \%$ & Párroco \\
\hline & & $33 \%$ & Domingo Cal (Rubiáns-Ourense) \\
\hline \multirow{2}{*}{\multicolumn{2}{|c|}{ Antes, san Cosmede }} & $67 \%$ & Párroco \\
\hline & & $33 \%$ & San Martiño de Xubia \\
\hline \multirow{2}{*}{\multicolumn{2}{|c|}{ Arcos, Santiago }} & $50 \%$ & Párroco \\
\hline & & $50 \%$ & Cabildo de Santiago \\
\hline \multirow{2}{*}{\multicolumn{2}{|c|}{ Beba, san Xián }} & $75 \%$ & Párroco \\
\hline & & $25 \%$ & Antonio Gómez (Compostela) \\
\hline \multicolumn{2}{|l|}{ Campolongo } & $100 \%$ & Párroco \\
\hline \multirow[t]{5}{*}{ Cando, san Tirso } & \multirow[t]{2}{*}{ Insua } & $50 \%$ & Párroco \\
\hline & & $50 \%$ & Pinario \\
\hline & \multirow[t]{2}{*}{ Toxeira- Ponte } & $50 \%$ & Párroco \\
\hline & & $50 \%$ & Toxosoutos \\
\hline & Resto & $100 \%$ & Párroco \\
\hline \multirow{3}{*}{\multicolumn{2}{|c|}{ Carnota }} & $50 \%$ & Manuel Varela (Ribadeneira-Lugo) \\
\hline & & $33 \%$ & Toribio Campillo (Compostela) \\
\hline & & $16 \%$ & Párroco \\
\hline \multirow[t]{3}{*}{ Chacín, santa Baia } & Santa Baia & $100 \%$ & Arcediano de Trastámara \\
\hline & \multirow[t]{2}{*}{ Resto } & $25 \%$ & Arcediano santa Tasia \\
\hline & & $75 \%$ & Cabildo de Santiago \\
\hline \multicolumn{2}{|l|}{ Coiro, santa María } & $100 \%$ & Párroco \\
\hline \multicolumn{2}{|l|}{ Corzón } & $100 \%$ & Párroco \\
\hline \multirow{2}{*}{\multicolumn{2}{|c|}{ Eirón, san Fins }} & $67 \%$ & Párroco \\
\hline & & $33 \%$ & Andrés García (Roma) \\
\hline \multicolumn{2}{|l|}{ Entíns, santa Leocadia } & $100 \%$ & Arcediano santa Tasia \\
\hline \multicolumn{2}{|l|}{ Entíns, santa María } & $100 \%$ & Párroco \\
\hline \multicolumn{2}{|l|}{ Entíns, santo Ourente } & $100 \%$ & Arcediano de Santa Tasia \\
\hline \multirow{3}{*}{\multicolumn{2}{|c|}{ Esteiro, Santa Mariña }} & $58 \%$ & Párroco \\
\hline & & $25 \%$ & Colexio Císter Salamanca \\
\hline & & $16 \%$ & José Pérez (Madrid) \\
\hline
\end{tabular}


MUNICIPIOS RURAIS NA GALICIA DO ANTIGO RÉXIME. O CASO DE VALLADARES: AUTOGOBERNO, XURISDICIÓN E LOITAS SEÑORIAIS

\begin{tabular}{|c|c|c|c|}
\hline \multirow[t]{3}{*}{ Fontecada, san Martiño } & \multirow[t]{2}{*}{ Igrexa } & $50 \%$ & Arcediano de Trastámara \\
\hline & & $50 \%$ & Marqués da Serra de Outes \\
\hline & Resto & $100 \%$ & Párroco \\
\hline \multirow{3}{*}{\multicolumn{2}{|c|}{ Louro, Santiago }} & $50 \%$ & Párroco \\
\hline & & $33 \%$ & Cabildo de Santiago \\
\hline & & $16 \%$ & Isidro Romero (Santiago) \\
\hline \multirow{2}{*}{\multicolumn{2}{|c|}{ Maroñas, santa Mariña }} & $50 \%$ & Párroco \\
\hline & & $50 \%$ & Marqués da Serra de Outes \\
\hline \multirow[t]{3}{*}{ Matasueiro } & \multirow[t]{2}{*}{ Lourido } & $50 \%$ & Pinario \\
\hline & & $50 \%$ & Párroco \\
\hline & Resto & $100 \%$ & párroco \\
\hline \multirow[t]{3}{*}{ Outeiro, san Cosme } & \multirow[t]{2}{*}{ Rates e Tabilo } & $37 \%$ & Pinario \\
\hline & & $63 \%$ & Párroco \\
\hline & Resto & $100 \%$ & Párroco \\
\hline \multirow[t]{2}{*}{ Roo, san Xoán } & Roo & $100 \%$ & Arcediano de Trastámara \\
\hline & Resto & $100 \%$ & Párroco \\
\hline \multicolumn{2}{|l|}{ Sabardes, san Xoán } & $100 \%$ & Sabardes-Pinario \\
\hline \multicolumn{2}{|l|}{ Sestaio, san Miguel } & $100 \%$ & Párroco \\
\hline \multirow{2}{*}{\multicolumn{2}{|c|}{ Tal, Santiago }} & $50 \%$ & Párroco \\
\hline & & $50 \%$ & Marqués de Santa Cruz \\
\hline \multicolumn{2}{|l|}{ Tarás } & $100 \%$ & Párroco \\
\hline \multirow{2}{*}{\multicolumn{2}{|c|}{ Torea, san Xián }} & $50 \%$ & Párroco \\
\hline & & $50 \%$ & Marqués de Santa Cruz \\
\hline \multirow{3}{*}{\multicolumn{2}{|c|}{ Valladares, san Miguel }} & $33 \%$ & Belvís \\
\hline & & $33 \%$ & Luis Outeiro (Morlán-Ourense) \\
\hline & & $33 \%$ & Párroco \\
\hline
\end{tabular}

O sistema de arrendamento supuña que o marxe de beneficio dependese do volume dos froitos recadados ou dos seus prezos, en relación ao remate do seu arrendamento. A persecución polo seu incremento levou aos arrendatarios a recorrer a distintas artimañas, consistentes nuns casos en variar as datas de percepción dos froitos para percibilos a mellor prezo, facendo uso a conveniencia do prezo asignado no ano da colleita ou no corrente, e noutros directamente a intentar o incremento dos prezos presionando ás xustizas ou restrinxindo a revenda do cereal para incrementalos. En 1740 é documentado un preito ante a 
Real Audiencia causado polas pretensións dos sincureiros de elevar os prezos ${ }^{49}$. En 1744 os procuradores don Ambrosio Bermúdez e don Tiburcio Hermida enfrontaranse co xuíz pola taxa de froitos que se debía facer tomando a alfóndega de Muros como referente ${ }^{50}$. No preito entre o mesmo procurador don Tiburcio e o xuíz Fracisco Silva denunciará tamén a fixación de prezos feita por este sen a súa asistencia ${ }^{51}$. En 1773 documentamos un preito cun particular, Bartolomé Campos pola mesma causa ${ }^{52}$. E, en 1776, co prior de Toxosoutos ao que a Real Audiencia mandaba cinguirse aos presos fixados pola xustiza de Muros $^{53}$.

En 1777 os mordomos de Roo, Outes e Carnota enfrontábanse ao xuíz e o seu escribán por negarse a calibrar os prezos tendo en conta á colleita do ano anterior en consonancia cos da vila de Noia, os sincureiros abusaban dos prezos percibindo a máis de 12 reais o ferrado de trigo e o de millo a máis de 8 , sen impedimento. Interposto o preito ante a Real Audiencia incorpóranse os rendistas como parte contraria, pero non é ata o mes de novembro que a Real Audiencia emite auto para que que se axusten aos $\operatorname{prezos}^{54}$.

Novamente entre 1781 é necesario o recurso dos procuradores síndicos de Muros á Real Audiencia para que rendistas e sincureiros respecten os prezos fixados polo xuíz ${ }^{55}$. En 1782 o proceso era entablado polo sincureiro da freguesía de Outes polo baixo prezo dos grans. En 1788 o problema atinxía diretamente aos curas de Cando, Outeiro, Roo, Outes, Valladares e Colúns, xunto co xuíz da xurisdición da Serra de Outes, e aos rendistas Clemente Domínguez e Bartolomé Porrúa, de Corcubión ${ }^{56}$. Nesta ocasión, o síndico debeu defender a posesión do concello de fixar os prezos.

Os vínculos existentes entre as elites económicas do alfoz levaban ao procurador de Valladares a denunciar ao xuíz ante a Real Audiencia en 1792:

que dando vuestra merced las manos con los comerciantes de vino de las feligresias de San Mamed de Carnota, San Esteban de Avilleyra, Santa Marina de Esteyra y San Juan de Sabardes y aunque esta está vaxo administración se debe arreglar al prezio que lo hazen en la villa de Noya no obstante dicha administración se debe mandar se venda a los seys quartos el quartillo lo venden a un

\footnotetext{
49 ARG, Real Audiencia, leg. 20.177, núm. 13, fols. 60-67.

${ }^{50}$ ARG, Real Audiencia, leg. 21.034, núm. 70, s. fol.

${ }^{51}$ ARG, Real Audiencia, leg. 26.250, núm. 59, s. fol.

${ }^{52}$ ARG, Real Audiencia, leg. 20.177, núm. 13, fols. 82-83.

${ }_{53}$ ARG, Real Audiencia, leg. 20.177, núm. 13, fols. 695-696.

${ }_{54}$ ARG, Real Audiencia, leg. 16.313, núm. 36, s. fol.

${ }_{55}$ ARG, Real Audiencia, leg. 20.177, núm. 13, fols. 31-32.

${ }^{56}$ ARG, Real Audiencia, leg. 20.177, núm. 13, s.fol. [últimos folios].
} 
ochabo menos debiendo venderlo a seis y en la tarbernas a cinco $y$ medio $^{57}$.

\section{Os AXENTES do ORde CAUSA DE DESORDE: Os XuíCES DE Muros}

Os xuíces de Muros, nomeados trienalmente polos arcebispos de Santiago, competíalles a administración de xustiza no alfoz da vila, así como todas aquelas tarefas que esta conlevaba: fixación de prezos, vixía de medidas, oficios artesanais, levas de soldados polo sistema de quintas, milicianos para o rexemento provincial e organización da rede de fachos costeiros, entre outras. No transcurso dos séculos XVII e sobre todo no XVIII a actividade neglixente ou temeraria destes é unha constante nas denuncias ante a Real Audiencia. En concreto, os problemas parecen multiplicarse a finais do século XVIII, e o seu tenor amosa o desinterese dos oficiais por exercer os seus labores no alfoz. Neste sentido apuntan todas as contravencións de don Domingo Malvar:

En esta jurisdicción ay el lugar de Valladares distinado con real provasión y para este efecto y para en él publicarse los reales y superiores órdenes a fin de que tengan debido cumplimiento y puntual observancia a causa de que se enteren de su contenido los mayordomos pedáneos y vasallos lo que se cumplió desde tiempo ynmemorial sin contrabensión alguna asistiendo el juez ordinario escrivano de gobierno político y procurador general deste indicado alfoz y ahora se experimenta la perjudicial nobedad de que vuestra merced lo repugna dirigiendo los enunciados órdenes por manos de mayordomo a mayordomo constándole muy bien los más de ellos no saben leer y algunos aunque seyan no entienden lo que se manda seguiéndose la falta de obserbansia y otros daños que dejo a la consideración de vuestra merced, y aunque pasé a vuestra merced varios oficios politicos sobre este particular permanece constante en su ynflecible determinación de abollir el precitado consejo en contravención de las reales disposiciones y en detrimento de la comodidad pública y para el remedio se lo represento ${ }^{58}$.

Ante isto, o procurador síndico recorrerá en varias ocasións á Real Audiencia, primeiro polos abusos en materia de fixación de prezos, atribuídas aos seus

\footnotetext{
${ }^{57}$ ARG, Real Audiencia, leg. 14.881, núm. 2, fol. 33.

58 ARG, Real Audiencia, leg. 14.881, núm. 2, fol. 2.
} 
vínculos con diversos comerciantes o xuíz será denunciado polo nomeamento dun tenente, cando a administración de xustiza nas súas ausencias era competencia do alcalde ou rexedor máis antigo da vila, ademais este era un home de mala conduta que xa desfalcara á xurisdición mor das levas de quintos:

Jacobo Llanes, sujetto de tan mala condutta en el sexto y séptimo precepto de la ley santa de Dios que tiene escandalizado toda la jurisdicción y echo gastar muchos miles de reales en el sorteo de quintos, y que se halla anulado, y aun tubo vuestra merced y tiene el atrevimiento de comicionarle para el alistamiento del siete por uno del explicado quinto quando que también sabe que no puede poner theniente.

A desafección do xuíz polo exercicio do seu cargo leva á ampliación de prerrogativas dos mordomos pedáneos limitándose a emitir ordes dirixidas a estes para as distintas necesidades: para a revisión de pesos e medidas faraos concorrer á vila onde se revisarán só os potes da xurisdición e non os particulares, avocando aos vecinos a concorrer a este e satisfacer 12 reais aos mordomos pedáneos pola súa comprobación; en canto á revista dos fachos desentenderase dela por considerala competencia do sarxento maior limitándose á remisión de ordes aos pedáneos ${ }^{59}$.

En agosto de 1792 a Real Audiencia manda ao xuíz cumplir cos costumes, empregar aos pedáneos só para facer concurrir ao concello e non se exceder na cobranza de dereitos, para emitir unha nova en maio de $1793^{60}$.

En 1793 Instando un arranxo o 24 de agosto de 1793 concedía unha escritura pola que acordaba devolver aos mordomos de cada parroquia parte dos cuartos entregados para a revisión das medidas:

Digo io don Domingo Antonio Malvar que me obligo entregar a los mayordomos que tengan entregado para manuferición y arreglamiento y testimonio de ello por las medidas de ferrados de sus feligresías a cada uno ocho reales conseguir lo acordado en el concejo de Valladares pagando los que las presentaron y arreglaron quatro reales por derechos de contraste marcador y carpintero

\footnotetext{
${ }^{59}$ Quanto a la revista de los trozos de la gente armada a la villa de Muros como capital de los fachos en la que bive el sargento mayor no lo ha dispuesto el que responde por ser peculiar de aquel pues solo remitió una orden a las feligresías para que concurriesen dos cada dia para hazer la revista general por la pasqua de resurrección según la ordenanza. ARG, Real Audiencia, leg. 14.881, núm. 2, fol. 19.

${ }^{60}$ ARG, Real Audiencia, leg. 14.881, núm. 2, fols. 13-15 e 44.
} 
que las arregló lo que entregara dentro de quince días como así mismo satisfacer la mitad de los salarios del receptor en caso haya partido antes de la transacción que oy hice con don Pasqual Cao y ara su resguardo doy el presente que firmo.

En 1794 sucédelle o herdeiro do marquesado de Monteleón. Pese á súa alta alcurnia trátase do persoeiro dunha liñaxe en decadencia económica, e, a tenor das denuncias contra él presentadas, tamén moral. Aínda que de condición noble perderá o seu título por non poder pagar o dereito de lanzas. Será denunciado tanto polos veciños como polos comerciantes de viño, por estes por cobrarlles elevadas taxas pola tasación do viño e pola veciñanza por alzar os prezos en contravención no acordado no concello de 5 reais a 6. A Real Audiencia obrigarao en decembro de 1794 a devolver aos comerciantes 163 reais que lles tiña levado ${ }^{61}$, finalmente será condeado en 20 ducados e as costas, pero o desacato fai que o tribunal emita unha segunda executoria mandando o cumprimento da primeira so pena de 100 ducados $^{62}$.

O seu sucesor don José Lema Romero será denunciado por non acudir ás xuntanzas do concello e descoidar a fixación de prezos o reparto de sisas e millóns, dación de contas dos síndicos saíntes, en conclusión, o concello parece estar funcionando sen presidente ${ }^{63}$.

\section{CONCLUSIÓNS}

O estudo dos concellos non só proporciona datos sobre istes, senón que a súa vinculación coas xurisdicións, das que moitas galegas parecen proceder da invención tardía dos seus señores ou tenentes de oficios de xuíces e prerrogativas, avanza pistas sobre a lexitimidade e orixe destes. No caso de Valladares este parece ser a orixe tanto do partido de Carnota como xurisdición separada do conde de Altamira e da xurisdición de Outes dos futuros marqueses da Serra de Outes. O presente estudo manifesta unha vida municipal tan rica e activa como a urbana e unha actividade defensiva-litigante moi superior e diversa, alonxada da mera loita por recursos comunais, fronte aos concellos urbanos onde os litixios eran en esencia oligárquicos.

As procuradorías do común foron oficios cobizados polas elites rurais e proporcionan unha radiografía das redes clientelares e os intereses contrapostos dos grupos do rural: eclesiásticos, rendistas-comerciantes e capitáns de milicias

\footnotetext{
${ }^{61}$ ARG, Real Audiencia, leg. 14.881, núm. 2, fols. 138-146.

${ }^{62}$ ARG, Real Audiencia, leg. 14.881, núm. 2, fol. 90.

${ }^{63}$ ARG, Real Audiencia, leg. 14.881, núm. 2, fol. 150.
} 
ocuparán o cargo sucesivamente, entre as súas redes en primeira instancia os parentes que servíndose dos seus oficios intentan promover o nomeamento, e, en segundo, dunhas redes só documentables no conflito, que intentan coa súa asistencia aos concellos incluso acompañados de xentes de armas obter a elección para os seus afines.

Como xa aconteceu no caso da vila esta análise proporciona unha imaxe do grupo rendista, fidalgo e non fidalgo, afastada da proporcionada pola historiografía tradicional, coma un grupo con iniciativa e implicación directa nas actividades mercantís, moi interesado pola vida política local, identificables con aqueles individuos que no XIX serán denominados caciques, e que no século XVIII eran xa denominados así na xurisdición ourensá de Bóveda de Amoeiro.

$\mathrm{O}$ presente artigo non ofrece máis que unha primeira aproximación xeral a unha realidade tan pouco estudada como a dos concellos rurais, quedando moitos focos de análise que cubrir e nos que profundizar. Entre as documentais destacamos a necesidade de estudo das redes familiares do rural a través da documentación sacramental, do funcionamento propiamente do concello na súa actividade gubernativa e ordenadora para a que contamos con diversa documentación recollida nos procesos da Real Audiencia, e da localización dos procesos seguidos con Corcubión ante o Xulgado de Guerra a finais do século XVIII.

\section{BIBLIOGRAFÍA}

Aguiar Andrade, Amélia, "Composição social e gestão municipal: o exemplo Ponte de Lima na Baixa Idade Media”, Ler Historia, 10 (1987), páxs. 3-13.

Alcalde Jiménez, José M., El poder del señorío. Señorío y poderes locales en Soria durante el Antiguo Régimen, León, Junta de Castilla y León, 1997.

Almeida Calheiros, Antonio, "A freguesía como unidade político-administrativa mínima en Portugal", A parroquia en Galicia pasado, presente e futuro, Santiago, Xunta de Galicia, 2009, páxs. 347-370.

Anes Duarte Nogueira, José A., “A estrutura administrativa dos municipios medievais. Alguns aspectos", Revista da Faculta de Direito da Universidade de Lisboa, 25 (1982), páxs. 249-317.

Armas Castro, José, Pontevedra en los siglos XII a XV. Configuración y desarrollo de una villa marinera en la Galicia medieval, A Coruña, Fundación Pedro Barrié de la Maza, conde de Fenosa, 1992.

Asenjo González, María, Segovia: la ciudad y su tierra a fines del Medievo, Segovia, Diputación Provincial de Segovia, 1986.

Botelho Cardoso, Isabel, Concelho e senhorio. O Porto (1385-1433), Porto, Facutade de Letras, 1993.

Burgo López, María Concepción, Un dominio monástico femenino en la Edad Moderna: el monasterio benedictino de San Paio de Antealtares, tese de doutoramento, Santiago, Universidade de Santiago de Compostela, 1996. 
Cammorosano, Paolo, "Le origini della fiscallitá publica della cittá italiane", Revista d'Historia Medieval, 7 (1996), páxs. 39-52.

Chevalier, Bernard, "Génese de la fiscalité urbaine en France", Revista d'Historia Medieval, 7 (1996), páxs. 21-38.

Carlé, María del Carmen, Del concejo medieval castellano leonés, Buenos Aires, Instituto de Historia de España, 1968, páxs. 11-39.

Cateura Bennasser, Pau, "Municipi i monarquia en la Mallorca dels segles XIII-XIV" Anales de la Universidad de Alicante. Historia Medieval, 13 (2002); páxs. 43-58.

Couceiro Gómez, Enrique, “Apuntes sobre la endogamia parroquial tradicional y sus condicionamientos socio-económicos e ideológicos en el Bajo Miño”, Anuario Brigantino, 14 (1991), páxs. 301-306.

Cruz Rodríguez, Joan, "El municipí igualadí medieval: una aproximació al seu funcionament (1282-circa 1388)", Miscellanea Aqualatensia, 8 (1997), páxs. 19-58.

Falçao Ferreira, María C., "Guimarães e Braga nos seculos XIII e XIV: uma questão de poderes", en $2^{\circ}$ Congresso Histórico de Guimarães, vol. 6, Guimarães, Universidade do Minho, 1997, páxs. 119-130.

Fernández Cortizo, Camilo, "Aldeas e caserías a tiro de mano de piedra: los asentamientos rurales en el arzobispado de Santiago (siglos XVI-XVIII)", Espacio, Tiempo y Forma, 4 (1997), páxs. 211-226.

Follain, Antoine, "Des communautés paroissales aux communs en Bretagnes et en Normandie. Un conflit pour l'identité communautaire", Annales de Bretagne et des Pays de l'Ouest, 104 (1997), páxs. 33-66.

García Oro, José y Portela Silva, María del Carmen, Los Mariño de Lobeira en la Galicia del Renacimiento: fortuna y desgracia de un señorio seglar del área compostelana, Santiago de Compostela, Caixa Galicia, 2003.

García Oro, José y Nóvoa Gómez, María de los Ángeles, La tierra de Deza en la Edad Media y en el Renacimiento. Del anonimato al pleito, Lalín, Concello de Lalín, 2000.

García Oro, José, Diego de Muros III y la cultura gallega del s. XV, Vigo, Galaxia, 1976.

García Valdeavellano, Luis, Curso de Historia de las Instituciones Españolas, Madrid, Biblioteca de ciencias Históricas, 1973.

Gibert, Rafael, "Estudio Histórico-jurídico", Anuario de Historia del Derecho Español, 52 (1953), páxs. 335-569.

González Balasch, María T., Tumbo B de la Catedral de Santiago, [Santiago de Compostela], Seminario de Estudios Galegos; Cabildo de la Catedral, 2004.

Hinojosa, Eduardo, "Origen del régimen municipal en León y Castilla”, en Estudios sobre la Historia del Derecho Español, Madrid, Asilo de Huérfanos del Sagrado Corazón de Jesús, 1903.

López Alsina, Fernando, "La articulación de las unidades de organización social del espacio en Galicia durante la Edad Media: villa, parroquia, terra", en La pervivencia del concepto. Nuevas reflexiones sobre la ordenación social del espacio en la Edad Media, Zaragoza, Universidad de Zaragoza, páxs. 57-111.

Martínez Llorente, Félix J., Régimen jurídico de la Extremadura castellana medieval, Valladolid, Universidad de Valladolid, 1990. 
Monsalvo Antón, José M., "Concejos castellano-leoneses y feudalismo (siglos XI-XII) Reflexiones para el estudio de la cuestión, Studia Historica. Historia Medieval, 10 (1992), páxs. 203-233.

Moreno Núñez, José I., Ávila y su tierra en la Baja Edad Media, siglos XIII-XV, Valladolid, Junta de Castilla y León, 1992.

Pousa Diéguez, Rodrigo, Señorios costeros y villas portuarias en la Galicia del s. XVIII: Corcubión, Muros y Noia, Vigo, Universidade de Vigo.

Pousa Diéguez, Rodrigo, "La administración de justicia ordinaria en la Corona de Castilla: la división jurisdiccional de Soria en la segunda mitad del siglo XVIII", Cuaderno de Historia Moderna, 45 (2020), páxs. 284-285.

Pousa Diéguez, Rodrigo, "Configuración institucional de una villa costera: Muros en el tránsito de la Edad Media a la Edad Moderna”, Espacio, Tiempo y Forma. Serie III. Historia Medieval, 34 (2021), páxs. 703-733.

Pousa Diéguez, Rodrigo, "La fisionomía del poder en la Castilla del siglo XVIII: poder jurisdiccional y poder concejil en Ávila”, Vínculos de Historia, 10 (2021) [en prensa].

Rodríguez Campos, Xaquín S., "Os espazos de identidade: reflexións desde a antropolxía social sobre a actualidade da parroquia rural en Galicia”, en A parroquia en Galicia: pasado presente e futuro, Santiago, Xunta de Galicia, 2009, páxs. 167-180.

Rodríguez Fernández, Agustín, Alcaldes y regidores. Administración territorial y gobierno municipal en Cantabria durante la Edad Moderna, Santander, Institución Cultural de Cantabria, 1986.

Rodríguez Fernández, Delfina, “Aldeas y parroquias. La estructuración del territorio en la comarca celanovesa a lo largo de los tiempos modernos", Homenaje a la prof. Lola Ferro, Vigo, Universidade de Vigo, páxs. 225-355.

Rubio Pérez, Laureano, "Poder o poderes. Señoríos, concejos y relaciones de poder en el mundo rural durante la Edad Moderna", en Aranda Pérez, Francisco (coord.) El mundo rural en la España Moderna, Cuenca, Universidad de Castilla La Mancha, 2004, páxs. 1081-1155.Rubio Pérez, Laureano, Visitas, juicios de residencia y poder concejil en la provincia de León, León, Universidad de León, 1998

Sacristán Martínez, Antonio, Municipalidades de Castilla y León. Estudio Histórico-crítico, Madrid, 1877, páxs. 213-221.

Sánchez, Manuel y Ortí, Pere, "La génesis de la fiscalidad municipal en Cataluña", Revistqa d'Historia Medieval, 7 (1996), páxs. 115-134.

Sánchez Martínez, Manuel, Fiscalidad de Estado y fiscalidad municipal en los reinos hispánicos medievales, Madrid, Casa de Velázquez, 2006.

Sánchez Pardo, José C., "Las iglesias rurales y su papel en la articulación territorial de Galicia medieval (ss. VI-XIII), Un caso de estudio”, Melánges de la Cas Velázquez 40 (2010), páxs. 149-170.

Sánchez Sánchez, Galo, Fueros castellanos de Soria y Alcalá de Henares, Madrid, Centro de Estudios Históricos, 1919.

Sobrado Correa, Hortensio, "Identidad parroquial y comunidad rural en la Galicia de la Edad Moderna”, en Campo y Campesinos en la España Moderna, Madrid, FEHM, 2012, páxs. 705-718. 
Vázquez Bertomeu, Mercedes, La hacienda arzobispal compostelana: libros de recaudación (1481-83 y 1486-91), Santiago de Compostela, CSIC, 2002 (Anejos de Cuadernos de Estudios Gallegos, 29).

Viciano, Pau y Mira, Antonio J., "La construcción d'un sistema fiscal: municipis i impost al Pais Valenciá (segles XIII-XIV)", Revistqa d'Historia Medieval, 7 (1996), páxs. 135-148.

Zink, Anne, Clochers et troupeaux. Les communautés rurales des Landes et Sud-Ouest Avant la révolution, Bourdeaux, Presees Universitaires, 1997. 
